\title{
A fuzzy AHP approach to select suppliers in the Brazilian food supply chain
}

\author{
Mayra Oliveira Ramos $^{\mathrm{a} *}$ (D), Eliciane Maria da Silva ${ }^{\mathrm{a}}$ (D), Francisco Rodrigues Lima-Júnior ${ }^{\mathrm{b}}$ \\ aUniversidade Metodista de Piracicaba, Santa Barbara d'Oeste, SP, Brasil \\ bUniversidade Tecnológica Federal do Paraná, Curitiba, PR, Brasil \\ *mayraolira@gmail.com
}

\begin{abstract}
Paper aims: This research proposes to apply the Fuzzy Analytical Hierarchy Process method for the supplier's selection in a Brazilian food company.

Originality: 1t is the first time that food security has been incorporated as a first-level criterion in a process of selecting suppliers in a Brazilian food chain.

Research method: Practical application was carried out in a food company located in Brazil.

Main findings: Safety is the most important criteria when selecting a supplier, which ended up reflecting the placement of Supplier 3 as the best rated.

Implications for theory and practice: This research provides the first practical application of a hybrid mathematical technique in the process of selecting suppliers in a Brazilian food chain, evaluating the Food Security criterion on an equal basis with the others, and not as a sub criterion. The model can help managers better understand their suppliers' capabilities and performance.
\end{abstract}

Keywords

Multicriteria decision-making method. Hybrid method. Food company. Supplier selection.

How to cite this article: Ramos, M. O., Silva, E. M., \& Lima-Júnior, F. R. (2020). A fuzzy AHP approach to select suppliers in the Brazilian food supply chain. Production, 30, e20200013. https://doi.org/10.1590/0103-6513.20200013.

Received: Feb. 10, 2020; Accepted: Oct. 8, 2020.

\section{Introduction}

There is an increasing concern with food safety, what makes the food industry suffer a lot of pressure from stakeholders (Font-i-Furnols \& Guerrero, 2014; Sepúlveda et al., 2011). Meeting the demand for food security is a challenge for developed and developing countries and depends on the combined efforts of government, regulators, academia, consumers, food producers and suppliers (Arisseto-Bragotto et al., 2017). In Brazil, the food and beverage sector plays a fundamental role in its emerging economy, it represents $9.6 \%$ of the country's Gross Domestic Product (GDP), corresponds to 61.7\% of the total trade balance and has a contingent of 37,7 thousand companies (Associação Brasileira da Indústria de Alimentos, 2020).

In this way, the food and beverage industry play an important role for Brazilian society, highlighting the need to respond to the challenges of this highly dynamic market (Freitas et al., 2020). Regarding to food security, is an issue that has become relevant in Brazil, there is a growing search for a better lifestyle and consumers' awareness of their rights to purchase healthy products. In this way, consumers value the production of highquality food with certification of origin and also obtained through Good Manufacturing Practices (GMP) and risk control (Spisso et al., 2009; Arisseto-Bragotto et al., 2017). 
According to Amorim et al. (2016) the food supply chains are more complex and have characteristics that makes them more difficult to manage when compared to other chains. The main difference is the perishability, the quality of the raw materials and the final product must be guaranteed from the moment they are dispatched from the producer until the moment they are consumed (Ahumada et al., 2012). The food industry must guarantee product quality, as food has a direct effect on consumers' health. To this end, companies must establish some practices to build the credibility of product brands and gain consumer trust and preference, such as traceability and guarantee of origin, quality and safety management system certificates, information labeling, among others (Souliotis et al., 2017).

Thus, to ensure that there is no interruption in the supply chain and the company's reputation is not tarnished, the food industry needs to guarantee the quality standard in its suppliers' processes and products to meet the requirements demanded by stakeholders through the processes of selection, evaluation and development of suppliers (Frej et al., 2017). In doing so, appropriate decisions can reduce purchasing costs and production lead time, for example, increasing customer satisfaction and strengthening organizations' competitiveness (Keramydas et al., 2016).

Selecting the best supplier is a vital component of the business relationship and one of the most critical issues in the competitive environment (Kannan et al., 2015). Therefore, it is important that their suppliers are well qualified and able to support organizational strategies (Banaeian et al., 2018). However, the challenge is not just to recognize the role of supplier management and practices, but rather to develop strategies and approaches for dealing with the supplier selection and evaluation processes (Chang \& Hung, 2010; Sarkis \& Dhavale, 2015).

The supplier selection process depends on many factors, since several decision criteria can be considered for evaluating the supply alternatives. This decision-making process should consider the quantitative and qualitative selection criteria that are often conflicting (Bai et al., 2017; Ekici, 2013), as well as a wide variety of supply alternatives (Sarkis \& Dhavale, 2015).

Voss et al. (2009) analyzed the influence of the supplier's price, delivery, quality and location on security suppliers in food supply chains in the USA. Among the conclusions of this study is that safety is more important, especially when the products come from abroad; buyers are then willing to purchase the product for a medium price. However, if buyers are not concerned about security incidents and source domestically, they are willing to purchase low price products. Thus, the emphasis on the quality of the raw material, delivery time and costs provide a new level of complexity for outsourcing and supplier selection decisions in this type of industry (Xiao \& Chen, 2010).

To deal with this complicated scenario, therefore, statistical techniques, multicriteria management decision methods and artificial intelligence have been explored when developing multicriteria decision-making models, which can be used singly or in combination by merging different methods (Ho et al., 2010). The Fuzzy AHP (Fuzzy Analytical Hierarchy Process) method can help managers carry out the supplier selection process, since it allows them to quantify the weights of multiple criteria and the ratings of suppliers using comparative judgments (Wang, 2010).

The FAHP method, developed by Chang (1996), was used in this research and has been the most widely adopted because it offers more advantages than other methods found in the literature (Ruoning \& Xiaoyan, 1992). These advantages include greater simplicity, ease of use and suitability to deal with subjective judgments given by decision makers. These characteristics contribute to a greater potential for applying the Fuzzy AHP method in practical cases of supplier selection (Lima-Junior et al., 2013; Kilincci \& Onal, 2011).

In the literature, some relevant articles articles have used hybrid decision-making methods to select or evaluate suppliers in the food supply chain (Magdalena, 2012; Liao, 2012; Lin \& Wu, 2011; Pasek, 2011; Nakandala et al., 2017; Rathore et al., 2017; Jafarzadeh Ghoushchi et al., 2019; Liu et al., 2019; Wang et al., 2020; Kaviani et al., 2020), including using the Fuzzy AHP technique (Azadnia et al., 2015; Khan et al., 2019). However, food security, when addressed, is incorporated as part of quality, not being assessed at the first level and separately as other criteria (e.g. delivery time, price and quality) (Pungchompoo \& Sopadang, 2015; Nakandala et al., 2017).

Another gap found in the literature is that few published articles (Araújo et al., 2015; Freitas et al., 2020) have studied the context of the Brazilian food industry specifically, applying mathematical techniques for selecting and evaluating suppliers. And none of which evaluated food security as a criterion for selecting and evaluating suppliers.

Regarding the practical context, the company under study does not use a mathematical decision-making technique to select and evaluate its suppliers, this process ends up being subjective and through self-assessment by the suppliers themselves, with forwarding of supporting documents and certificates.

Thus, this work seeks to fill these gaps, both theoretical and practical, providing a far-reaching mathematical decision-making method in the context of the Brazilian food supply chain, taking into account evaluation 
criteria appropriate to the country's requirements and with a clear interface for practical application, helping decision makers to better understand their suppliers' capabilities and performance by enabling them to identify and reduce purchase risk.

Due the importance of the food sector for the Brazilian economy and the complexity of the criteria that are involved in the supplier selection process in the food business, this research proposes applying a multicriteria decision model based on the FAHP method for selecting suppliers in a food company. The aim of this research is to answer the following questions: How can the FAHP method be applied to support the selection of suppliers in a Brazilian food industry? Which criteria are most important when selecting suppliers in a Brazilian food supply chain?

Section 2 presents the literature review on the supplier selection process and multicriteria decision-making techniques. Section 3 provides the steps of the decision-making technique used (FAHP), and the data collection and analysis procedures performed in the case study. Section 4 presents the results with the application of the tool in the food supply chain. Section 5 presents a discussion of the results found with the previous literature. Section 6 concludes the article.

\section{Theoretical background for supplier selection process}

Because of the high dependence between organizations regarding purchasing, the suppliers' selection is one of the most important and strategic processes, making organizations seek for long-term relationships with their suppliers based on trust and commitment, so that favorable results can be achieved in the chain (Frej et al., 2017; Parthiban et al., 2013).

Under a procedural view, Aissaoui et al. (2007) structured the supplier selection process in four interrelated steps that aim to identify a set of possible suppliers and reduce it until the final choice, these being: problem's definition; criteria's formulation; qualification, and; final choice.

In defining the problem, strategic purchasing issues need to be highlighted. Some companies, for example, look for suppliers only to expand the variety of their products, while others seek to develop partnerships and long-term contracts. In this way, to make the right choice, the decision-making agent must initially clearly define what the objectives of the selection process are (Lima-Junior et al., 2014).

In the moment to define the criteria it is important to highlight that besides the strategic vigor, the supplier selection is also considered complex by the fact that a lot of criteria are consider in the decision-making process, ranging from the operational to the strategic level (Chai et al., 2013). In the literature in general, quality of material, labor expertise, product cost, on time delivery, after sales service, environmental certificates, were cited by several authors as being important criteria for selecting suppliers (Banaeian et al., 2018; Govindan et al., 2014). In the food supply chain, there are different criteria and relevant specificities employed for selecting and assessing suppliers (Djekic et al., 2015).

Food industries generally select a raw material supplier based on the supplier's price, flavor or location, as governments further emphasize the importance of considering qualitative and quantitative criteria, such as food safety and quality (Prusak et al., 2013). Quality includes using food technology to measure shelf-life, freshness, size, and taste, but it may have a specific meaning; in the chicken meat chain, for example, quality aspects change according to the perception of the players in the chicken meat chain (Ali et al., 2017).

Food safety refers to reducing the likelihood of delivering a product compromised by accidental contamination, causing the product to result in illness, injury, death or negative consequences for people, goods or equipment. The ISO 22000 standard concerns food safety as an integral part of a broader standardized management system (Liu et al., 2012; Marucheck et al., 2011).

For the qualification and final choice process, to deal with a large number of criteria, several supplier selection problems in the literature are addressed within a multi-criteria approach, and different MCDM methods are applied to evaluate the alternatives, according to the Decision Makers (DM) preference structure, in the context of the problem (Almeida et al., 2015).

\subsection{Multicriteria decision-making techniques for supplier selection}

The decision-making process involves multiple criteria, aiming to find the best option from a set of viable alternatives, or to classify the alternatives (Govindan \& Cheng, 2018). These criteria can be both quantitative and qualitative. Qualitative criteria are those decision factors that cannot be easily expressed in numerical terms 
and are based on a set of variables that alter in a specific domain, while quantitative relationships were defined as existing between these variables (Alexander et al., 2018; Silva et al., 2020).

After defining the criteria that will be part of the supplier's selection process in which the decision-making model will be generated, the most appropriate mathematical technique for use with the problem as defined is chosen (Govindan et al., 2017).

In recent decades, several MCDM methods have been effectively applied for managing the supplier selection problem, and the use of hybrid methods that combine more than two techniques has received recent attention due to their flexibility; for example, articles have used diffuse heuristic techniques combined with MCDM analytical models, such as AHP, TOPSIS and SWARA (Lima-Junior \& Carpinetti, 2016).

Table 1 presents some of the techniques found in the literature, using fuzzy set theory with MCDM techniques, that were used to select suppliers, for example, Fuzzy and AHP, Fuzzy and TOPSIS, and Fuzzy and SWARA. With regard to the supplier selection problem in the food industry, there is limited amount of literature discussing formal reference frameworks (Magdalena, 2012; Liao, 2012; Lin \& Wu, 2011; Pasek, 2011; Azadnia et al., 2015; Nakandala et al., 2017; Rathore et al., 2017; Jafarzadeh Ghoushchi et al., 2019; Khan et al., 2019; Liu et al., 2019; Wang et al., 2020; Kaviani et al., 2020), especially in the Brazilian context (Araújo et al., 2015; Freitas et al., 2020)

Table 1. Decision techniques for supplier selection models in the food industry.

\begin{tabular}{|c|c|}
\hline Decision Methods & Authors \\
\hline Fuzzy ANP and Goal Programming & Magdalena et al. (2020) \\
\hline Intuitionistic Fuzzy AHP & Kaviani et al. (2020) \\
\hline Fuzzy BWM and Piece wise linear values & Jafarzadeh Ghoushchi et al. (2019) \\
\hline Fuzzy DEA & Hatami-Marbini et al. (2017) \\
\hline Fuzzy Axiomatic Design & Kannan et al. (2015) \\
\hline Fuzzy MOM & Hashim et al. (2017) \\
\hline Fuzzy AHP & $\begin{array}{l}\text { Lu et al. (2007); Zimmer et al. (2017); Azadnia et al. (2015); Khan et al. } \\
\text { (2019) }\end{array}$ \\
\hline Fuzzy AHP and VIKOR & Awasthi et al. (2018) \\
\hline Fuzzy TOPSIS & Govindan et al. (2013); Kannan et al. (2014); Sen et al. (2016) \\
\hline Fuzzy SWARA and MOORA & Mavi et al. (2017) \\
\hline Fuzzy TOPSIS and CRITICS & Rostamzadeh et al. (2018) \\
\hline Fuzzy Delphi DEMATEL, ANP and PROMETHEE & Govindan et al. (2017) \\
\hline Fuzzy TOPSIS and SCOR & Lima-Junior \& Carpinetti (2016) \\
\hline SEM, Fuzzy AHP and MOLP & Jakhar (2015) \\
\hline Fuzzy TOPSIS and MSGP & Liao (2012) \\
\hline Taguchi loss function and Fuzzy AHP & Magdalena (2012) \\
\hline Fuzzy AHP and TOPSIS & Rathore et al. (2017); Liu et al. (2019); Wang et al. (2020) \\
\hline Fuzzy Delphi and AHP & $\operatorname{lin} \& W u(2011)$ \\
\hline Fuzzy AHP, TOPSIS and ELECTREE & Nakandala et al. (2017) \\
\hline PROMETHEE & Araújo et al. (2015) \\
\hline AHP & Freitas et al. (2020) \\
\hline
\end{tabular}

AHP: Analytical Hierarchy Process; ANP: Analytic Network Process; BWM: Best-Worst Method; CRITICS: Criteria Importance Through Inter-criteria Correlation; DEA: Data Envelopment Analysis; DEMATEL: Decision making trial and evaluation laboratory; MOLP: Multi-objective Linear Programming; MOM: Mean of Maximum; MOORA: Multi-Objective Optimization based on Ratio Analysis; MSGP: Multi-Segment Goal Programming; PROMETHEE: Preference Ranking Organization Method for Enrichment Evaluations; SCOR: Supply Chain Operation Reference; SEM: Supplier Risk Management; TOPSIS: Technique for Ordering Preference by Similarity to ldeal Solution; SWARA: The Step-wise Weight Assessment Ratio Analysis; VIKOR: Multicriteria Optimization and Compromise Solution; ELECTREE: Elimination Et Choix Traduisant la REalité. Source: Elaborated by the authors.

In practice, in order to obtain a good result in the supplier selection process, it is necessary to obtain massive data collection through research, investigation and sampling. However, this data is not always available. In this way, decisions are based on qualitative data that are generally influenced by the subjective opinion of the decision maker when defining the weights of criteria and suppliers. Therefore, there is a degree of uncertainty in the decision-making process caused by the subjective assessment of qualitative or quantitative criteria (ie, limited rationality of various decision makers who rely on limited historical data) (Oztaysi, 2014; Banaeian et al., 2018).

Thus, a model based on the subjective preferences of a decision maker is not always accurate, as it requires a great deal of knowledge, specialization and experience (Liu et al., 2017). To deal with biased data, "diffuse" approaches are applied to MCDM problems, as the incorporation of diffuse sets in decision-making models can produce more realistic results since they aim to transform uncertain human knowledge into a mathematical 
formula (Zadeh, 1965). In this paper, we discuss the steps for the development and implementation of fuzzy AHP for evaluation and selection of suppliers for a food processing company.

\section{Method}

\subsection{Fuzzy Analytic Hierarchy Process (FAHP)}

Saaty (1987) was responsible for developing the AHP method, which aims to hierarchically structure the problem into criteria and sub-criteria, making a comparison between them. Decision-makers, however, may be uncertain about this comparison. Therefore, the FAHP was developed to help DMs to resolve the vague nature of the alternative selection problem (Ganguly \& Guin, 2013; Cobo et al., 2019).

This paper utilizes the five step FAHP method proposed by Chang (1996) to determine criterion weight for the supplier selection problem. The steps are described below:

1. Identify the decision makers responsible for supplier selection so they determine the selection criteria and the alternatives, and then model the problem as a hierarchy containing the decision goal;

2. Define a set of comparative language terms to quantify the supplier's performance and the weight of the criteria. The triangular fuzzy numbers corresponding to each language term must also be defined. Table 2 presents a set of suggested language terms for comparing suppliers, and the decision criteria and triangular fuzzy numbers corresponding to each language term;

Table 2. Comparative linguistic scale used to assess the importance of the criteria and alternatives.

\begin{tabular}{cc}
\hline Linguistic Terms & Fuzzy Triangular Number \\
\hline Equally Preferable (EP) & $(1.00,1.00,3.00)$ \\
Slightly Preferable (SP) & $(1.00,3.00,5.00)$ \\
Fairly Preferable (FP) & $(3.00,5.00,7.00)$ \\
Extremely Preferable (EXP) & $(5.00,7.00,9.00)$ \\
Absolutely Preferable (AP) & $(7.00,9.00,9.00)$ \\
\hline
\end{tabular}

Source: Elaborated by the authors.

3. Using the set of values in Table 2, each specialist should evaluate the importance of the decision criteria and supplier performance in relation to the criteria adopted;

4. Check the consistency of the fuzzy judgments that have been collected. A consistent decision matrix is sufficiently consistent if: $C C I=0.31$ for $n=3 ; C C I=0.35$ for $n=4$, and; $C C I=0.37$ for $n>4$. Judgments that do not meet this requirement should be reviewed. The computation for checking the consistency of the judgments was in accordance with (Bulut et al., 2012);

5. The measures in the hierarchy are evaluated in two iterations. The first iteration consists in determining the weights of the criteria. In this case, the criteria are objects that have different levels of importance in relation to the objectives of supplier selection. Thus, for each criterion ${ }^{i}$, one must obtain a measure of preference $M_{g i}^{j}$ in relation to the goal of decision $j$, where $M$ is a triangular fuzzy number and $g$ (goal) is only an element that is frequently used in this notation.

The second iteration consists in evaluating the suppliers and involves the objects of the second and third levels of the hierarchy. In this case, how alternatives $i$ satisfy different objectives (decision criteria) must be quantified. Thus, for each alternative $i$ and each specialist $k$, a measure of preference $M_{g i}^{j}$ must be obtained in relation to decision criteria $k$. The following procedures should be performed in each of the interactions:

1. Let $X=\left\{x_{1}, x_{2}, x_{3}, \ldots x_{n}\right\}$ an object set, and $G=\left\{g_{1,} g_{2}, g_{3,} \ldots g_{m}\right\}$ be a goal set and $M_{g i}^{j}=(i=1,2 \ldots m, j=1,2 \ldots m)$ all are triangular fuzzy numbers. The value of fuzzy synthetic extent of the $i t h$ object for $m$ goals is defined as:

$$
S_{i}=\sum_{j=1}^{m} M_{g i}^{j} \otimes\left[\sum_{i=j}^{n} \sum_{j=1}^{m} M_{g i}^{j}\right]^{-1}=\left(\frac{1}{\sum_{i=j}^{n} u_{i}}, \frac{1}{\sum_{i=j}^{n} m_{i}}, \frac{1}{\sum_{i=J}^{n} l_{i}}\right)
$$


2. After obtaining the synthetic mean of all objects it is calculated the degree of possibility $S_{2} \geq\left(l_{2}, m_{2}, u_{2}\right) \geq S_{1}\left(l_{l}, m_{1}, u_{1}\right)$, where $S_{1}$ and $S_{2}$ are given by Equation 1. The degree of possibility between two fuzzy synthetic extents is defined as in Equation 2.

$$
V\left(S_{2} \geq S_{1}\right)=\sup _{x \geq y}\left[\min \left(\mu_{S 2}(y), \mu_{S 1}(x)\right)\right]
$$

which can be equivalently expressed as in Equations 3 and 4.

$$
\begin{gathered}
V\left(S_{2} \geq S_{1}\right)=h g t\left(S_{1} \cap S_{2}\right)=\mu_{S 2}(d) \\
\mu_{S_{2}}(d)=\left\{\begin{array}{c}
1, \text { if } m_{2} \geq m_{1} \\
0, \text { if } l_{1} \geq u_{2} \frac{l_{1}-u_{2}}{\left(m_{2}-u_{2}\right)-\left(m_{1}-l_{1}\right)}, \\
\text { otherwise }
\end{array}\right\}
\end{gathered}
$$

The $d$, in Equation 3 and 4, represents the ordinate of the highest intersection between $\mu_{S 1}$ and $\mu_{S 2}$, as illustrated in Figure 1. The comparison between $M_{1}$ and $M_{2}$ requires the values of $V\left(S_{2} \geq S_{1}\right)$ and $V\left(S_{1} \geq S_{2}\right)$.

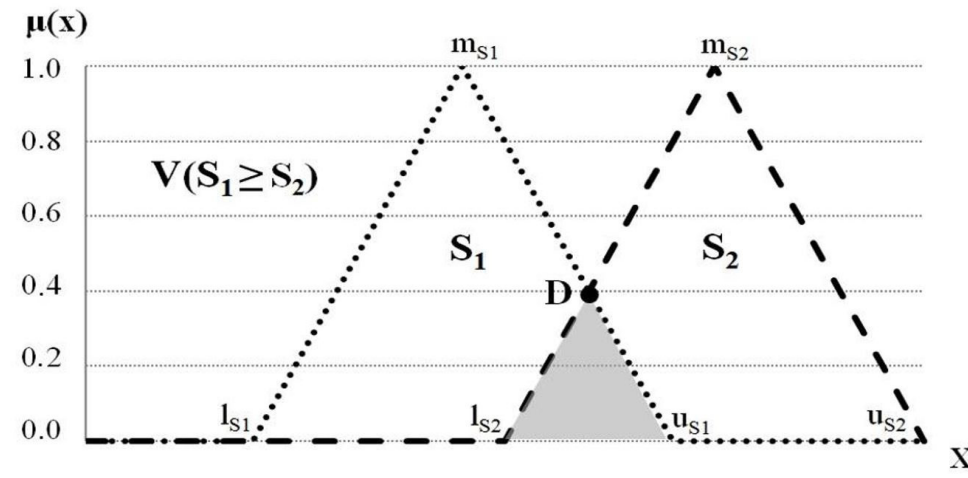

Figure 1. The intersection between $S_{1}$ and $S_{2}$. Source: Based on Chang (1996) and Lima-Junior et al. (2014).

3. Calculate the degree of possibility for a convex fuzzy number to be greater than $k$ convex fuzzy numbers $S_{i}(i=1, \ldots, k)$ according to Equation 5 :

$$
V\left(S \geq S_{1}, S_{2}, \ldots, S_{k}\right)=V\left[( S \geq S _ { 1 } ) \text { and } ( S \geq S _ { 2 } ) \ldots \text { and } \left(S \geq S_{k}=\min V\left(S \geq S_{i}\right), i=1,2, \ldots, k .\right.\right.
$$

4. The weight vector is given by:

$$
W=\left(d^{\prime\left(A_{l}\right)}, d^{\prime\left(A_{2}\right)}, \ldots d^{\prime\left(A_{k}\right)}\right)^{T}, d^{\prime} A_{i}=\min V\left(S \geq S_{i}\right), \text { for } i=1,2, \ldots=1,2, \ldots, k \neq j
$$

5. The normalized weight vector is calculated as:

$$
W^{\prime}=\left(d\left(A_{1}\right), d\left(A_{2}\right), \ldots d\left(A_{k}\right)\right)^{T}
$$

In which $W$ is a non-fuzzy number worked out for each comparison matrix.

\subsection{Application case}

In this document a comprehensive supplier-selection model is proposed considering important food industry criteria. The case study was carried out in a food company located in Brazil, which was founded in 1992 and serves the meat packing industry. This company aims to ensure total traceability, from approval of the raw materials to obtaining the finished products and delivery to the customer. The company trains its employees in 
quality programs, such as 5S, Good Manufacturing Practices (GMP), Hazard Analysis and Critical Control Points (HACCP), and has ISO 9001 Quality Management certification.

The first phase of the research consisted in identifying the main criteria used by the company to select its suppliers. To this end, an initial interview in loco was conducted with the manager of the quality sector, who was responsible for the supplier selection. This manager provided information on how the process worked in the company and made available the documents used to select and evaluate its suppliers, enabling the identification of the criteria to compose the structure hierarchy of the decision-making problem.

In the second phase, Maltodextrin was defined as the product to be analyzed because it is a raw material widely used in the manufacture of several products. There are also four suppliers available for selection, in this paper we named as Supplier 1 (S1), Supplier 2 (S2), Supplier 3 (S3), and Supplier 4 (S4). A second interview, that happened remotely, was subsequently conducted with the quality manager, who is the only decision maker, in order to evaluate the weight of each criterion and the ratings of each supplier. The third phase aimed at ordering suppliers according to their overall performance using the FAHP method (Chang, 1996). The decision model was implemented using Microsoft Excel software.

\section{Results}

From the interviews with the decision maker it was possible to determine the criteria and sub-criteria used by the studied company when selecting its suppliers; these are set out in Figure 2. After defining the criteria, the decision maker evaluated the weightings of the decision criteria using the linguistic judgments. Table 3 presents the evaluation for the first level criteria, while Table 4 presents the performance ratings of suppliers for Conservation status (E1).

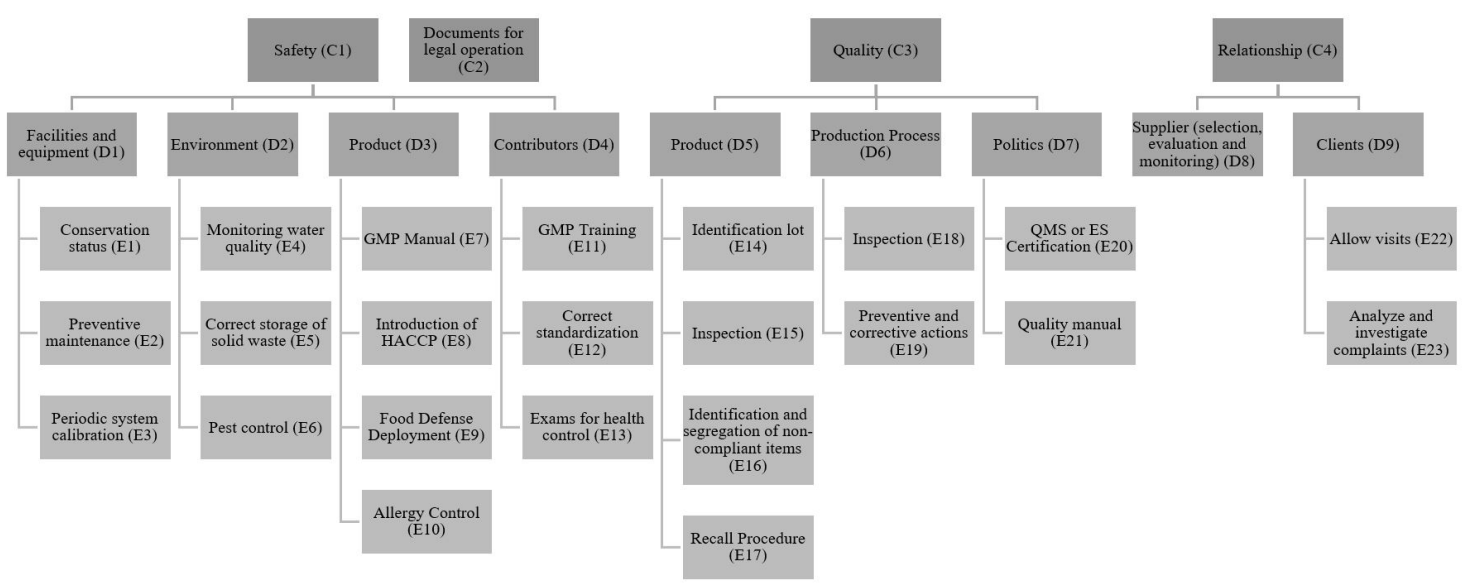

Figure 2. Hierarchical structure of the first, second and third level criteria. GMP: Good manufacturing practices; HACCP: Hazard Analysis of Critical Control Point; QMS: Quality Management System; ES: Environmental System. Source: Elaborated by the authors.

Table 3. Expert linguistic judgments about the importance of first-level decision criteria.

\begin{tabular}{ccccc}
\hline & $\mathrm{C} 1$ & $\mathrm{C} 2$ & $\mathrm{C} 3$ & $\mathrm{C} 4$ \\
\hline $\mathrm{C} 1$ & $\mathrm{SP}$ & $\mathrm{EXP}$ & $\mathrm{EP}$ \\
$\mathrm{C} 2$ & & $\mathrm{SP}$ & $\mathrm{SP}$ & $\mathrm{EP}$ \\
$\mathrm{C} 3$ & & & & $\mathrm{EP}$ \\
\hline
\end{tabular}

Source: Elaborated by the authors.

Table 4. Linguistic judgments about supplier performance for Conservation status (E1).

\begin{tabular}{ccccc}
\hline & S1 & S2 & S3 & S4 \\
\hline S1 & & $1 / \mathrm{SP}$ & SP & $\mathrm{FP}$ \\
S2 & & $1 / \mathrm{SP}$ & $\mathrm{FP}$ \\
S3 & & & \\
S4 & & & \\
\hline
\end{tabular}

Source: Elaborated by the authors. 
The linguistic judgments were subsequently transformed into triangular fuzzy numbers. Tables 5 and 6 show the values of linguistic judgments converted into fuzzy triangular numbers. The value of the Centric Consistency lndex $(\mathrm{CCl})$ was calculated for each matrix of the hierarchical structure, according to Bulut et al. (2012). Tables 5 and 6 show the $\mathrm{CCl}$ of their matrices, which are consistent because they have $\mathrm{n}=4$ and their $\mathrm{CCl}$ is less than 0.35 . The $\mathrm{CCl}$ was consistent for all the matrices in this research but will not be shown in the text due to the extension of the results.

Table 5. Fuzzy number values corresponding to first level criteria weights.

\begin{tabular}{ccccc}
\hline & $\mathrm{C} 1$ & $\mathrm{C} 2$ & $\mathrm{C} 3$ & $\mathrm{C} 4$ \\
\hline $\mathrm{C} 1$ & $(1.00,1.00,1.00)$ & $(1.00,3.00,5.00)$ & $(5.00,7.00,9.00)$ & $(3.00,5.00,7.00)$ \\
$\mathrm{C} 2$ & $(0.20,0.33,1.00)$ & $(1.00,1.00,1.00)$ & $(1.00,3.00,5.00)$ & $(1.00,3.00,5.00)$ \\
$\mathrm{C} 3$ & $(0.11,0.14,0.20)$ & $(0.20,0.33,1.00)$ & $(1.00,1.00,1.00)$ & $(1.00,1.00,3.00)$ \\
$\mathrm{C} 4$ & $(0.14,0.20,0.33)$ & $(0.20,0.33,1.00)$ & $(0.33,1.00,1.00)$ & $(1.00,1.00,1.00)$ \\
& $\mathrm{CCl}$ & & 0.026 & \\
\hline
\end{tabular}

Source: Elaborated by the authors.

Table 6. Fuzzy numbers values of the alternative ratings related to criterion $E_{1}$

\begin{tabular}{ccccc}
\hline & S1 & S2 & S3 & S4 \\
\hline S1 & $(1.00,1.00,1.00)$ & $(0.20,0.33,1.00)$ & $(0.20,0.33,1.00)$ & $(1.00,3.00,5.00)$ \\
S2 & $(1.00,3.00,5.00)$ & $(1.00,1.00,1.00)$ & $(0.20,0.33,1.00)$ & $(3.00,5.00,7.00)$ \\
S3 & $(1.00,3.00,5.00)$ & $(1.00,3.00,5.00)$ & $(1.00,1.00,1.00)$ & $(3.00,5.00,7.00)$ \\
S4 & $(0.20,0.33,1.00)$ & $(0.14,0.20,0.33)$ & $(0.14,0.20,0.33)$ & $(1.00,1.00,1.00)$ \\
& CCl & & 0.026 \\
\hline
\end{tabular}

Source: Elaborated by the authors.

In order to synthesize the preferences of the hierarchy, in the first iteration a synthetic measurement value of each of the evaluated criteria was calculated using Equation 1.

$$
\begin{gathered}
S_{c 1}=(10.00,20.00,22.00) \otimes\left(\frac{1}{42.53}, \frac{1}{32.33}, \frac{1}{17.31}\right)=(0.24,0.62,1.27) \\
S_{c 2}=(3.20,7.33,12.00) \otimes\left(\frac{1}{42.53}, \frac{1}{32.33}, \frac{1}{17.31}\right)=(0.08,0.23,0.69) \\
S_{c 3}=(2.31,2.47,5.20) \otimes\left(\frac{1}{42.53}, \frac{1}{32.33}, \frac{1}{17.31}\right)=(0.05,0.08,0.30) \\
S_{c 4}=(1.80,2.53,3.33) \otimes\left(\frac{1}{42.53}, \frac{1}{32.33}, \frac{1}{17.31}\right)=(0.04,0.08,0.19)
\end{gathered}
$$

The degrees of possibility of these fuzzy values are based on Equations 3 and 4:

$$
\begin{aligned}
& V\left(S_{C 1} \geq S_{C 2}\right)=1.00 \\
& V\left(S_{C 1} \geq S_{C 3}\right)=1.00 \\
& V\left(S_{C 1} \geq S_{C 4}\right)=1.00 \\
& V\left(S_{C 2} \geq S_{C 1}\right)=0.54 \\
& V\left(S_{C 2} \geq S_{C 3}\right)=1.00 \\
& V\left(S_{C 2} \geq S_{C 4}\right)=1.00 \\
& V\left(S_{C 3} \geq S_{C 1}\right)=0.11
\end{aligned}
$$




$$
\begin{aligned}
& V\left(S_{C 3} \geq S_{C 2}\right)=0.60 \\
& V\left(S_{C 3} \geq S_{C 4}\right)=0.99 \\
& V\left(S_{C 4} \geq S_{C 1}\right)=0.00 \\
& V\left(S_{C 4} \geq S_{C 2}\right)=0.44 \\
& V\left(S_{C 4} \geq S_{C 3}\right)=1.00
\end{aligned}
$$

Consequently, the weight vector W, calculated as in Equations 5 and 6, is:

$$
\begin{aligned}
& d^{\prime}\left(C_{1}\right)=V\left[\left(S_{C 1} \geq S_{C 2}\right) \text { and }\left(S_{C 1} \geq S_{C 3}\right) \text { and }\left(S_{C 1} \geq S_{C 4}\right) \text { and }\left(S_{C 1} \geq S_{C 5}\right)\right]=\min (1.00,1.00,1.00)=1.00 \\
& d^{\prime}\left(C_{2}\right)=V\left[\left(S_{C 2} \geq S_{C 1}\right) \text { and }\left(S_{C 2} \geq S_{C 3}\right) \text { and }\left(S_{C 2} \geq S_{C 4}\right) \text { and }\left(S_{C 2} \geq S_{C 5}\right)\right]=\min (0.54,1.00,1.00)=0.54 \\
& d^{\prime}\left(C_{3}\right)=V\left[\left(S_{C 3} \geq S_{C 1}\right) \text { and }\left(S_{C 3} \geq S_{C 2}\right) \text { and }\left(S_{C 3} \geq S_{C 4}\right) \text { and }\left(S_{C 3} \geq S_{C 5}\right)\right]=\min (0.11,0.60,0.99)=0.11 \\
& d^{\prime}\left(C_{4}\right)=V\left[\left(S_{C 4} \geq S_{C 1}\right) \text { and }\left(S_{C 4} \geq S_{C 2}\right) \text { and }\left(S_{C 4} \geq S_{C 3}\right) \text { and }\left(S_{C 4} \geq S_{C 5}\right)\right]=\min (0.00,0.44,1.00)=0.00
\end{aligned}
$$

Therefore, the weight vector is defined by Equation 28.

$$
W=(1.00,0.54,0.11,0.00)
$$

The weight vector after normalization is:

$$
W^{\prime}=(0.61,0.33,0.07,0.00)
$$

The same calculations were performed for the second and third level criteria. In order to find the weight vectors of the suppliers' final score, the same calculation procedures were used in the second iteration of the fuzzy AHP method. Equations 30, 31, 32 and 33 show the calculation of the synthetic preference measures of suppliers in relation to the third level criterion, Conservation Status (E1).

$$
\begin{aligned}
& S_{S 1}=(2.40,4.66,8.00) \otimes\left(\frac{1}{42.66}, \frac{1}{27.72}, \frac{1}{15.08}\right)=(0.06,0.17,0.53) \\
& S_{S 2}=(5.20,9.33,14.00) \otimes\left(\frac{1}{42.66}, \frac{1}{27.72}, \frac{1}{15.08}\right)=(0.12,0.34,0.93) \\
& S_{S 3}=(6.00,12.00,18.00) \otimes\left(\frac{1}{42.66}, \frac{1}{27.72}, \frac{1}{15.08}\right)=(0.14,0.43,1.19) \\
& S_{S 4}=(1.48,1.73,2.66) \otimes\left(\frac{1}{42.66}, \frac{1}{27.72}, \frac{1}{15.08}\right)=(0.03,0.06,0.18)
\end{aligned}
$$

According to Equations 3 and 4, using the same comparative procedures demonstrated in Equations 12 to 23 for each criterion evaluated, a preference measure was obtained of the synthetic measures of each alternative in relation to the others. Equations 34 to 45 show the values obtained by the alternatives in relation to the third level criterion, Conservation Status (E1).

$$
\begin{aligned}
& V\left(S_{S 1} \geq S_{S 2}\right)=1.00 \\
& V\left(S_{S 1} \geq S_{S 3}\right)=1.00 \\
& V\left(S_{S 1} \geq S_{S 4}\right)=1.00
\end{aligned}
$$




$$
\begin{aligned}
& V\left(S_{S 2} \geq S_{S 1}\right)=0.54 \\
& V\left(S_{S 2} \geq S_{S 3}\right)=1.00 \\
& V\left(S_{S 2} \geq S_{S 4}\right)=1.00 \\
& V\left(S_{S 3} \geq S_{S 1}\right)=0.11 \\
& V\left(S_{S 3} \geq S_{S 2}\right)=0.60 \\
& V\left(S_{S 3} \geq S_{S 4}\right)=0.99 \\
& V\left(S_{S 4} \geq S_{S 1}\right)=0.00 \\
& V\left(S_{S 4} \geq S_{S 2}\right)=0.44 \\
& V\left(S_{S 4} \geq S_{S 3}\right)=1.00
\end{aligned}
$$

Consequently, the weight vector W, calculated as in Equations 5 and 6, is:

$$
\begin{aligned}
& d^{\prime}\left(S_{1}\right)=V\left[\left(S_{S 1} \geq S_{S 2}\right) \text { and }\left(S_{S 1} \geq S_{S 3}\right) \text { and }\left(S_{S 1} \geq S_{S 4}\right) \text { and }\left(S_{S 1} \geq S_{S 5}\right)\right]=\min (0.71,0.60,1.00)=0.60 \\
& d^{\prime}\left(S_{2}\right)=V\left[\left(S_{S 2} \geq S_{S 1}\right) \text { and }\left(S_{S 2} \geq S_{S 3}\right) \text { and }\left(S_{S 2} \geq S_{S 4}\right) \text { and }\left(S_{S 2} \geq S_{S 5}\right)\right]=\min (1.00,0.89,1.00)=0.89 \\
& d^{\prime}\left(S_{3}\right)=V\left[\left(S_{S 3} \geq S_{S 1}\right) \text { and }\left(S_{S 3} \geq S_{S 2}\right) \text { and }\left(S_{S 3} \geq S_{S 4}\right) \text { and }\left(S_{S 3} \geq S_{S 5}\right)\right]=\min (1.00,1.00,1.00)=1.00 \\
& d^{\prime}\left(S_{4}\right)=V\left[\left(S_{S 4} \geq S_{S 1}\right) \text { and }\left(S_{S 4} \geq S_{S 2}\right) \text { and }\left(S_{S 4} \geq S_{S 3}\right) \text { and }\left(S_{S 4} \geq S_{S 5}\right)\right]=\min (0.53,0.17,0.09)=0.09
\end{aligned}
$$

Therefore, the weight vector is defined by Equation 50 .

$$
W=(0.60,0.89,1.00,0.09)
$$

The weight vector after normalization is defined by Equation 51:

$$
W^{\prime}=(0.23,0.34,0.39,0.03)
$$

The same calculations were performed to obtain the performance vector of the suppliers in relation to each of the decision criteria evaluated. Table 7 summarizes all the normalized weight vectors of the criteria and alternatives.

Finally, using the normalized weight vectors related to the performance of suppliers and the normalized weight vectors of the criteria, (which are generated from the sum of the weights of the first, second and third level criteria) the global performance of each alternative was calculated. For supplier alternative A1, the global performance was computed as:

$$
\begin{aligned}
& D\left(S_{1}\right)=\left(d^{\prime}\left(S_{1 E 1}\right) \times d^{\prime}\left(E_{1}\right) \times d^{\prime}\left(D_{1}\right) \times d^{\prime}\left(C_{1}\right)\right)+ \\
& \left(\left(d^{\prime}\left(S_{1 E 2}\right) \times d^{\prime}\left(E_{2}\right) \times d^{\prime}\left(D_{1}\right) \times d^{\prime}\left(C_{1}\right)\right)+\right. \\
& \left(\left(d^{\prime}\left(S_{1 E 3}\right) \times d^{\prime}\left(E_{3}\right) \times d^{\prime}\left(D_{1}\right) \times d^{\prime}\left(C_{1}\right)\right)+\ldots+\right. \\
& \left(d^{\prime}\left(S_{1 E 23}\right) \times d^{\prime}\left(E_{23}\right) \times d^{\prime}\left(D_{9}\right) \times d^{\prime}\left(C_{4}\right)\right)=0.19
\end{aligned}
$$

Table 8 presents the ranking of the alternatives constructed from ordering the relative performance values obtained. Following this procedure, alternative $S_{3}$ is the best evaluated supplier, followed by $S_{2}, S_{4}, S_{1}$, in this order. 
Tabe 7. Normalized weight vectors of criteria and alternatives

\begin{tabular}{|c|c|c|c|c|c|c|}
\hline $\begin{array}{c}\text { First level } \\
\text { criteria }\end{array}$ & Second level criteria & Third level criteria & $W^{\prime}{ }_{S 1}$ & $W^{\prime}{ }_{S 2}$ & $W_{S 3}^{\prime}$ & $W_{S 4}^{\prime}$ \\
\hline \multirow{13}{*}{$W_{C 1}^{\prime}=0.61$} & \multirow{3}{*}{$W_{D 1}^{\prime}=0.45$} & $W_{E 1}^{\prime}=0.44$ & 0.23 & 0.34 & 0.39 & 0.03 \\
\hline & & $W_{E 2}^{\prime}=0.36$ & 0.03 & 0.52 & 0.19 & 0.24 \\
\hline & & $W_{E 3}^{\prime}=0.19$ & 0.11 & 0.31 & 0.35 & 0.22 \\
\hline & \multirow{3}{*}{$W_{D 2}^{\prime}=0.30$} & $W_{E 4}^{\prime}=0.36$ & 0.06 & 0.29 & 0.37 & 0.27 \\
\hline & & $W_{E 5}^{\prime}=0.44$ & 0.25 & 0.25 & 0.25 & 0.25 \\
\hline & & $W_{E 6}^{\prime}=0.00$ & 0.07 & 0.09 & 0.34 & 0.49 \\
\hline & \multirow{4}{*}{$W_{D 3}^{\prime}=0.25$} & $W_{E 7}^{\prime}=0.44$ & 0.26 & 0.10 & 0.25 & 0.39 \\
\hline & & $W_{E 8}^{\prime}=0.55$ & 0.25 & 0.11 & 0.32 & 0.31 \\
\hline & & $W_{E 9}^{\prime}=0.00$ & 0.26 & 0.11 & 0.38 & 0.24 \\
\hline & & $W_{E 10}^{\prime}=0.87$ & 0.28 & 0.36 & 0.25 & 0.10 \\
\hline & \multirow{3}{*}{$W_{D 4}^{\prime}=0.00$} & $W_{E 11}^{\prime}=0.12$ & 0.25 & 0.00 & 0.18 & 0.56 \\
\hline & & $W_{E 12}^{\prime}=0.00$ & 0.25 & 0.15 & 0.32 & 0.26 \\
\hline & & $W_{E 13}^{\prime}=0.00$ & 0.25 & 0.25 & 0.25 & 0.25 \\
\hline \multirow[t]{4}{*}{$W_{C 2}^{\prime}=0.33$} & & & 0.23 & 0.13 & 0.30 & 0.32 \\
\hline & \multirow{4}{*}{$W_{D 5}^{\prime}=0.33$} & $W_{E 14}^{\prime}=0.28$ & 0.25 & 0.25 & 0.25 & 0.25 \\
\hline & & $W_{E 15}^{\prime}=0.43$ & 0.18 & 0.39 & 0.35 & 0.08 \\
\hline & & $W_{E 16}^{\prime}=0.20$ & 0.25 & 0.12 & 0.32 & 0.31 \\
\hline \multirow{5}{*}{$W_{C 3}^{\prime}=0.07$} & & $W_{E 17}^{\prime}=0.08$ & 0.27 & 0.21 & 0.34 & 0.17 \\
\hline & \multirow{2}{*}{$W_{D 6}^{\prime}=0.33$} & $W_{E 18}^{\prime}=0.70$ & 0.11 & 0.37 & 0.30 & 0.22 \\
\hline & & $W_{E 19}^{\prime}=0.30$ & 0.25 & 0.25 & 0.25 & 0.25 \\
\hline & \multirow{2}{*}{$W_{D 7}^{\prime}=0.33$} & $W_{E 20}^{\prime}=0.50$ & 0.24 & 0.30 & 0.30 & 0.14 \\
\hline & & $W_{E 21}^{\prime}=0.50$ & 0.25 & 0.25 & 0.25 & 0.25 \\
\hline \multirow{3}{*}{$W^{\prime}{ }_{C 4}=0.00$} & $W_{D 8}^{\prime}=0.70$ & & 0.20 & 0.26 & 0.26 & 0.27 \\
\hline & \multirow{2}{*}{$W_{D 9}^{\prime}=0.29$} & $W_{E 22}^{\prime}=0.00$ & 0.25 & 0.25 & 0.25 & 0.25 \\
\hline & & $W_{E 23}^{\prime}=0.00$ & 0.22 & 0.34 & 0.40 & 0.03 \\
\hline
\end{tabular}

Table 8. Global performance of alternatives and outranking using min. operator

\begin{tabular}{ccc}
\hline Alternative & Normalized global scores & Rank \\
\hline S1 & 0.19 & $4^{\text {th }}$ \\
S2 & 0.27 & $2^{\text {nd }}$ \\
S3 & 0.30 & $1^{\text {st }}$ \\
S4 & 0.26 & $3^{\text {rd }}$ \\
\hline
\end{tabular}

Source: Elaborated by the authors.

The criterion evaluated as the most important (received the highest score in relation to the others), according to the DM, was the Safety criterion (C1), and Supplier 3 (S3) was the one that obtained the highest scores for this criterion, this made him stand out in relation to the other suppliers.

Another important factor that made S3 the 1st place was its constant scores in relation to all other criteria. Supplier 2 (S2), for example, had high scores for Safety criteria (C1), such as Conservation Status (E1), Preventive maintenance (E2), Periodic system calibration (E3) and Allergy Control (E10), however also presented low marks for Pest control (E6), GMP Manual (E7), GMP Training (E11). This made S2 the second best rated. Supplier 1 (S1) was the one with the lowest scores in the criteria considered most important (Safety (C3)), which made it the worst rated.

\section{Discussion}

From the results found, for the company studied, the criteria related to food security are the most important for selecting and evaluating its suppliers, followed by the requirement of legal documents where the company checks whether its suppliers present all authorizations, licenses, grants and permits required for legal operation. 
In Brazil, the responsible bodies that discuss international food standards (e.g. Codex Alimentarius Commission, European Commission and US Food and Drug Administration) and formulate responses to express and support local proposals related to these standards are: Ministry Health (Ministério da Saúde), through its National Health Surveillance Agency (Agência Nacional de Vigilância Sanitária - ANVISA), and; Ministry of Agriculture, Livestock and Supply (Ministério da Agricultura, Pecuária e Abastecimento - MAPA) (Arisseto-Bragotto et al., 2017).

Among the standards and management systems required by the studied company are: 1SO 9001 (for Quality Management); $1 S 022000$ (for Food Safety); Hazard Analysis and Critical Control Points (Management System focused on food security); British Retail Consortium (Food Safety System Certification); Food Safety System Certification 22000; Manual of Good Manufacturing Practices (in Portuguese, Boas Práticas de Fabricação); Kosher (Certification that involves specific norms of the Orthodox Jewish diet), and; HALAL (Certification that involves specific rules of the Muslim diet). These cover a set of measures that must be adopted by the food industries and food services, in order to guarantee the sanitary quality and the conformity of food with technical regulations (Agência Nacional de Vigilância Sanitária, 2020).

Thus, for the company under study, following the requirements and complying with the established international and national standards, stand out as the most important criteria when selecting a supplier, which ended up reflecting the placement of Supplier 3 (S3) as the best rated, since their scores in all criteria were consistent, especially for the Safety criterion (C1).

This result reflects compliance with the law issued by ANVISA (Resolution RDC No. 216 of September 15, 2004), which provides for the Technical Regulation of Good Practices for Food Services, and states that the receipt of raw materials is important to ensure the safety of the final product, therefore, it is essential that suppliers follow the principles of good practices, especially in the area of receipt, process control and evaluation of suppliers and transport system (Brasil, 2004).

Nakandala et al. (2017), in their work on fresh food supplier evaluation, reinforces the importance of using food safety criteria to select and evaluate suppliers, highlighting the need to reach a minimum level of food safety standards to have a more in-depth assessment of the supplier.

In other works, published in the literature, the criteria price/cost and delivery time, for example, are commonly used to select or evaluate suppliers in the food supply chain (Araújo \& Alencar, 2015; Freitas et al., 2020; Kaviani et al., 2020; Magdalena et al., 2020; Wang et al., 2020). In the paper of Freitas et al. (2020), for example, the most relevant criteria for decision makers were cost and delivery time. However, for the company under study, these criteria are not taken into account in the selection and evaluation of its suppliers, reflecting that for this chain these requirements are not as significant as Safety, Quality and Relationship, for example.

Regarding the evaluation of criteria related to sustainability, the only one evaluated by the food industry under study is the certification of Quality System (ISO 9001) or Environmental System (ISO 14001), and this criterion is not so important for the company when compared to others (Security or Legal Documents). Evaluation criteria related to sustainability, such as: Environmental emissions, Environmental planning, Eco design, Solid Waste, Employment, Employee Satisfaction, Work Conditions, Human Rights, Gender and Diversity, are not evaluated in detail, demonstrating that these aspects are not priorities for the food company studied.

In the research carried out by Freitas et al. (2020), the authors identified and evaluated the main criteria related to sustainability used in the supplier's selection process of Brazilian companies in the food sector, by using AHP technique. As result, the authors founded that the economic criteria (Cost, Quality, Delivery Time, among others) obtained greater weight in relation to environmental and social criteria. In addition, it was found that environmental issues are gaining importance due to the market value they represent. This change, although still small, has been beneficial in preserving the environment.

Thereby, companies in the food sector in Brazil prioritize economic issues of sustainable use to select suppliers, and have a growing interest in environmental criteria as these result in market value. However, social and ethical issues, as important as the others, still have little importance and visibility in this sector (Galuchi et al., 2019; Freitas et al., 2020; Pereira et al., 2020).

\section{Final remarks}

According to the literature, few papers have applied mathematical techniques to support supplier's selection in the food supply chain and approached food security as a first level criteria, especially in the Brazilian context (Magdalena, 2012; Nakandala et al., 2017; Rathore et al., 2017; Jafarzadeh Ghoushchi et al., 2019; Liu et al., 2019; Wang et al., 2020; Kaviani et al., 2020; Azadnia et al., 2015; Khan et al., 2019; Araújo et al., 2015; Freitas et al., 2020). 
Thus, this research contributes to the literature and fills the gaps found by providing the first practical application of a hybrid mathematical technique (FAHP), used as a support method for the supplier selection process in a Brazilian food supply chain, evaluating the Food Security criterion on an equal basis with others, and not as a sub-criterion of Quality. Another point is the use of the hierarchy of criteria divided into 3 sub-levels, since most studies use only one or two sub-levels. In this way, the use of the 3-level hierarchy, combined with the wide diversity of sub-criteria adopted, can contribute to a more detailed/effective assessment of the supplier's profile and performance.

Supplier selection based on the FAHP multicriteria method helps identify the importance level of the criteria and sub-criteria based on linguistic judgments. It also allows the overall performance of suppliers to be quantified by considering multiple criteria and sub-criteria so as to indicate those most appropriate for partnerships.

Because of the ease of use of the FAHP, it stands out as a method that covers the complexity of the decisionmaking problem, in this case, supplier selection, considering multiple hierarchically-organized criteria, and provides the versatility needed to adapt to different types of problem and practicality for application in food industries.

By applying the study in a practical manner, it was possible to provide to the company being studied with additional information and to establish a systematic approach to its supplier selection and evaluation process. The model proposed can be adapted for use in different organizations that wish to identify the best alternatives for multicriteria decision-making problems involving quantitative and qualitative variables. The approach also helps managers better understand the capabilities and performance of their suppliers, enabling them to identify and reduce purchase risks and improve the performance of their suppliers.

One of the limitations of this research is that it considers a small/limited number of respondents/decision makers. As a suggestion, therefore, future researchers should possibly increase the number of respondents, while the problem can be formulated using other multicriteria decision-making methods for comparing the results. Furthermore, there should be a focus on assigning weights to decision-makers according to their expertise, experience and responsibilities, which are not equal. Future work can also better investigate the importance of social and ethical criteria in the Brazilian food supply chain.

\section{Acknowledgements}

This study was financed in part by Coordenação de Aperfeiçoamento de Pessoal de Nível Superior - Brasil (CAPES) - Finance Code 001.

\section{References}

Agência Nacional de Vigilância Sanitária - ANVISA. (2020). Boas práticas de fabricação: serviços de alimentos, regularização de empresas: alimentos. Retrieved in 2020, August 27, from http://portal.anvisa.gov.br/registros-e-autorizacoes/alimentos/empresas/ boas-praticas-de-fabricacao

Ahumada, O., Rene Villalobos, J., \& Nicholas Mason, A. (2012). Tactical planning of the production and distribution of fresh agricultural products under uncertainty. Agricultural Systems, 112, 17-26. http://dx.doi.org/10.1016/j.agsy.2012.06.002.

Aissaoui, N., Haouari, M., \& Hassini, E. (2007). Supplier selection and order lot sizing modeling: a review. Computers \& Operations Research, 34(12), 3516-3540. http://dx.doi.org/10.1016/j.cor.2006.01.016.

Alexander, A., Kumar, M., \& Walker, H. (2018). A decision theory perspective on complexity in performance measurement and management. International Journal of Operations \& Production Management, 38(11), 2214-2244. http://dx.doi.org/10.1108/1J0PM-10-2016-0632.

Ali, M. H., Tan, K. H., \& lsmail, M. D. (2017). A supply chain integrity framework for halal food. British Food Journal, 119(1), 20-38. http://dx.doi.org/10.1108/BFJ-07-2016-0345.

Almeida, N. M., Sousa, V., Dias, L. A., \& Branco, F. (2015). Engineering risk management in performance-based building environments. Journal of Civil Engineering and Management, 21(2), 218-230. http://dx.doi.org/10.3846/13923730.2013.802740.

Amorim, P., Curcio, E., Almada-Lobo, B., Barbosa-Póvoa, A. P. F. D., \& Grossmann, l. E. (2016). Supplier selection in the processed food industry under uncertainty. European Journal of Operational Research, 252(3), 801-814. http://dx.doi.org/10.1016/j.ejor.2016.02.005.

Araújo, M. C. B., \& Alencar, L. H. (2015). Integrated model for supplier selection and performance evaluation. South African Journal of Industrial Engineering, 26(2), 41-55. http://dx.doi.org/10.7166/26-2-880.

Araújo, M. C. B., Alencar, L. H., \& Viana, J. C. (2015). Structuring a model for supplier selection. Management Research Review, 38(11), 1-22. http://dx.doi.org/10.1108/MRR-04-2014-0076.

Arisseto-Bragotto, A. P., Feltes, M. M. C., \& Block, J. M. (2017). Food quality and safety progress in the Brazilian food and beverage industry: chemical hazards. Food Quality and Safety, 1(2), 117-129. http://dx.doi.org/10.1093/fqsafe/fyx009.

Associação Brasileira da Indústria de Alimentos - ABIA. (2020) Relatório anual 2019. Retrieved in 2020, August 27, from https://www. abia.org.br/vsn/temp/z202055RelatorioAnual2019.pdf

Awasthi, A., Govindan, K., \& Gold, S. (2018). Multi-tier sustainable global supplier selection using a fuzzy AHP-VIKOR based approach. International Journal of Production Economics, 195, 106-117. http://dx.doi.org/10.1016/j.jpe.2017.10.013. 
Azadnia, A. H., Saman, M. Z. M., \& Wong, K. Y. (2015). Sustainable supplier selection and order lot-sizing: An integrated multi-objective decision-making process. International Journal of Production Research, 53(2), 383-408. http://dx.doi.org/10.1080/00207543.20 14.935827.

Bai, L., Li, Y., Du, Q., \& Xu, Y. (2017). A fuzzy comprehensive evaluation model for sustainability risk evaluation of PPP projects. Sustainability, 9(10), 1890. http://dx.doi.org/10.3390/su9101890.

Banaeian, N., Mobli, H., Fahimnia, B., Nielsen, 1. E., \& Omid, M. (2018). Green supplier selection using fuzzy group decision making methods: a case study from the agri-food industry. Computers and Operations Research, 89, 337-347. http://dx.doi.org/10.1016/j. cor.2016.02.015.

Brasil, Agência Nacional de Vigilância Sanitária - ANVISA. (2004, September 15). Regulamento técnico de boas práticas para serviços de alimentação (Resolução RDC $n^{\circ}$ 216, de 15 de setembro de 2004). Diário Oficial da República Federativa do Brasil..

Bulut, E., Duru, O., Keçeci, T., \& Yoshida, S. (2012). Use of consistency index, expert prioritization and direct numerical inputs for generic fuzzy-AHP modeling: a process model for shipping asset management. Expert Systems with Applications, 39(2), $1911-1923$. http://dx.doi.org/10.1016/j.eswa.2011.08.056.

Chai, J., Liu, J. N. K., \& Ngai, E. W. T. (2013). Application of decision-making techniques in supplier selection: a systematic review of literature. Expert Systems with Applications, 4O(10), 3872-3885. http://dx.doi.org/10.1016/j.eswa.2012.12.040.

Chang, B., \& Hung, H. F. (2010). A study of using RST to create the supplier selection model and decision-making rules. Expert Systems with Applications, 37(12), 8284-8295. http://dx.doi.org/10.1016/j.eswa.2010.05.056.

Chang, D. Y. (1996). Applications of the extent analysis method on fuzzy AHP. European Journal of Operational Research, 95(3), 649655. http://dx.doi.org/10.1016/0377-2217(95)00300-2.

Cobo, A., Rocha, E. R., \& Villamizar, M. A. (2019). Innovative propensity with a fuzzy multicriteria approach: analysis of the Spanish industrial sector with data mining techniques. Management Decision, 5711), 2940-2957. http://dx.doi.org/10.1108/MD-10-2017-0954.

Djekic, 1., Skunca, D., Nastasijevic, 1., Tomovic, V., \& Tomasevic, 1. (2015). Transformation of quality aspects throughout the chicken meat supply chain. British Food Journal, 120(5), 1132-1150. http://dx.doi.org/10.1108/BFJ-08-2017-0432.

Ekici, A. (2013). An improved model for supplier selection under capacity constraint and multiple criteria. International Journal of Production Economics, 141(2), 574-581. http://dx.doi.org/10.1016/j.jpe.2012.09.013.

Font-i-Furnols, M., \& Guerrero, L. (2014). Consumer preference, behavior and perception about meat and meat products: an overview. Meat Science, 98(3), 361-371. http://dx.doi.org/10.1016/j.meatsci.2014.06.025. PMid:25017317.

Freitas, A., Salgado, E. G., \& Sousa Lira, J. M. (2020). Selection of suppliers in the green supply chain: case study with multi-criteria decision. International Journal of Qualitative Research, 14(1), 51-64. http://dx.doi.org/10.24874/1JQR14.01-04.

Frej, E. A., Roselli, L. R. P., Araújo de Almeida, J., \& de Almeida, A. T. (2017). A multicriteria decision model for supplier selection in a food industry based on FITradeoff method. Mathematical Problems in Engineering, 2017, 1-9. http://dx.doi.org/10.1155/2017/4541914.

Galuchi, T. P. D., Rosales, F. P., \& Batalha, M. 0. (2019). Management of socioenvironmental factors of reputational risk in the beef supply chain in the Brazilian Amazon region. The International Food and Agribusiness Management Review, 22(2), 155-171. http:// dx.doi.org/10.22434/IFAMR2018.0004.

Ganguly, K. K., \& Guin, K. K. (2013). A fuzzy AHP approach for inbound supply risk assessment. Benchmarking, 20(1), 129-146. http:// dx.doi.org/10.1108/14635771311299524.

Govindan, K., \& Cheng, T. C. E. (2018). Advances in stochastic programming and robust optimization for supply chain planning. Computers \& Operations Research, 100, 262-269. http://dx.doi.org/10.1016/j.cor.2018.07.027.

Govindan, K., Azevedo, S. G., Carvalho, H., \& Cruz-Machado, V. (2014). Impact of supply chain management practices on sustainability. Journal of Cleaner Production, 85, 212-225. http://dx.doi.org/10.1016/j.jclepro.2014.05.068.

Govindan, K., Kadzi $\square$ ski, M., \& Sivakumar, R. (2017). Application of a novel PROMETHEE-based method for construction of a group compromise ranking to prioritization of green suppliers in food supply chain. Omega, 71, 129-145. http://dx.doi.org/10.1016/j. omega.2016.10.004.

Govindan, K., Khodaverdi, R., \& Jafarian, A. (2013). A fuzzy multi criteria approach for measuring sustainability performance of a supplier based on triple bottom line approach. Journal of Cleaner Production, 47, 345-354. http://dx.doi.org/10.1016/j.jclepro.2012.04.014.

Hashim, M., Nazam, M., Yao, L., Ahmad Baig, S., Abrar, M., \& Zia-ur-Rehman, M. (2017). Application of multi-objective optimization based on genetic algorithm for sustainable strategic supplier selection under fuzzy environment. Journal of Industrial Engineering and Management, 10(2), 188-212. http://dx.doi.org/10.3926/jiem.2078.

Hatami-Marbini, A., Agrell, P. J., Tavana, M., \& Khoshnevis, P. (2017). A flexible cross-efficiency fuzzy data envelopment analysis model for sustainable sourcing. Journal of Cleaner Production, 142, 2761-2779. http://dx.doi.org/10.1016/j.jclepro.2016.10.192.

Ho, W., Xu, X., \& Dey, P. K. (2010). Multi-criteria decision making approaches for supplier evaluation and selection: a literature review. European Journal of Operational Research, 202(1), 16-24. http://dx.doi.org/10.1016/j.ejor.2009.05.009.

Jafarzadeh Ghoushchi, S., Khazaeili, M., Amini, A., \& Osgooei, E. (2019). Multi-criteria sustainable supplier selection using piecewise linear value function and fuzzy best-worst method. Journal of Intelligent \& Fuzzy Systems, 37(2), 2309-2325. http://dx.doi. org/10.3233/JlFS-182609.

Jakhar, S. K. (2015). Performance evaluation and a flow allocation decision model for a sustainable supply chain of an apparel industry. Journal of Cleaner Production, 87(1), 391-413. http://dx.doi.org/10.1016/j.jclepro.2014.09.089.

Kannan, D., Govindan, K., \& Rajendran, S. (2015). Fuzzy axiomatic design approach based green supplier selection: a case study from Singapore. Journal of Cleaner Production, 96, 194-208. http://dx.doi.org/10.1016/j.jclepro.2013.12.076.

Kannan, D., Jabbour, A. B. L. S., \& Jabbour, C. J. C. (2014). Selecting green suppliers based on GSCM practices: using Fuzzy TOPSIS applied to a Brazilian electronics company. European Journal of Operational Research, 233(2), 432-447. http://dx.doi.org/10.1016/j. ejor.2013.07.023.

Kaviani, M. A., Peykam, A., Khan, S. A., Brahimi, N., \& Niknam, R. (2020). A new weighted fuzzy programming model for supplier selection and order allocation in the food industry. Journal of Modelling in Management, 15(2), 381-406. http://dx.doi.org/10.1108/ JM2-11-2018-0191. 
Keramydas, C., Papapanagiotou, K., Vlachos, D., \& lakovou, E. (2016). Risk management for agri-food supply chains. In E. lakovou, D. Bochtis, D. Vlachos \& D. Aidonis (Eds.), Supply chain management for sustainable food networks. Chichester: John Wiley \& Sons. http://dx.doi.org/10.1002/9781118937495.ch10.

Khan, S., Khan, M. 1., Haleem, A., \& Jami, A. R. (2019). Prioritising the risks in Halal food supply chain: an MCDM approach. Journal of Islamic Marketing. In press. http://dx.doi.org/10.1108/JIMA-10-2018-0206.

Kilincci, O., \& Onal, S. A. (2011). Fuzzy AHP approach for supplier selection in a washing machine company. Expert Systems with Applications, 38(8), 9656-9664. http://dx.doi.org/10.1016/j.eswa.2011.01.159.

Liao, C.-N. (2012). Applying fuzzy-MSGP approach for supplier evaluation and selection in food industry. African Journal of Agricultural Research, 7(5). http://dx.doi.org/10.5897/ajarx11.088.

Lima Junior, F. R., Osiro, L., \& Carpinetti, L. C. R. (2013). Multicriteria decision methods for supplier selection: a literature review on the state of the art. Gestão \& Produção, 20(4), 781-801. http://dx.doi.org/10.1590/S0104-530X2013005000005.

Lima Junior, F. R., Osiro, L., \& Carpinetti, L. C. R. (2014). A comparison between Fuzzy AHP and Fuzzy TOPSIS methods to supplier selection. Applied Soft Computing, 21, 194-209. http://dx.doi.org/10.1016/j.asoc.2014.03.014.

Lima-Junior, F. R., \& Carpinetti, L. C. R. (2016). Combining SCOR ${ }^{\circledR}$ model and fuzzy TOPSIS for supplier evaluation and management. International Journal of Production Economics, 174, 128-141. http://dx.doi.org/10.1016/j.jpe.2016.01.023.

Lin, P. C., \& Wu, L. S. (2011). How supermarket chains in Taiwan select suppliers of fresh fruit and vegetables via direct purchasing. Service Industries Journal, 31(8), 1237-1255. http://dx.doi.org/10.1080/02642060903437568.

Liu, H. C., Liu, L., Liu, N., \& Mao, L.-X. (2012). Risk evaluation in failure mode and effects analysis with extended VIKOR method under fuzzy environment. Expert Systems with Applications, 39(17), 12926-12934. http://dx.doi.org/10.1016/j.eswa.2012.05.031.

Liu, H., Wei, X., Wang, Z., Geng, L., \& Li, C. (2017). Experimental investigation of performance effect of working parameters on bi-evaporator compression /ejection refrigeration system. New York: American Society of Mechanical Engineers. http://dx.doi. org/10.1115/POWER-ICOPE2017-3198.

Liu, Y., Eckert, C., Yannou-Le Bris, G., \& Petit, G. (2019). A fuzzy decision tool to evaluate the sustainable performance of suppliers in an agrifood value chain. Computers \& Industrial Engineering, 127, 196-212. http://dx.doi.org/10.1016/j.cie.2018.12.022.

Lu, L. Y. Y., Wu, C. H., \& Kuo, T. C. (2007). Environmental principles applicable to green supplier evaluation by using multi-objective decision analysis. International Journal of Production Research, 45(18-19), 4317-4331. http://dx.doi.org/10.1080/00207540701472694.

Magdalena, R. (2012). Supplier selection for food industry: a combination of taguchi loss function and fuzzy analytical hierarchy process. The Asian Journal of Technology Management, 5(1), 13-22.

Magdalena, R., Dias, S. P., \& Ginting, A. P. (2020). Allocation of maltodextrin raw material orders by Fuzzy Analytic Network Process (FANP) and Goal Programming Methods (Study Case: PT. Neopangan Selaras Indonesia). IOP Conference Series. Materials Science and Engineering, 8471), 012016. http://dx.doi.org/10.1088/1757-899X/847/1/012016.

Marucheck, A., Greis, N., Mena, C., \& Cai, L. (2011). Product safety and security in the global supply chain: lssues, challenges and research opportunities. Journal of Operations Management, 29(7-8), 707-720. http://dx.doi.org/10.1016/j.jom.2011.06.007.

Mavi, R. K., Goh, M., \& Zarbakhshnia, N. (2017). 'Sustainable third-party reverse logistic provider selection with fuzzy SWARA and fuzzy MOORA in plastic industry. International Journal of Advanced Manufacturing Technology, 91(5-8), 2401-2418. http://dx.doi. org/10.1007/s00170-016-9880-x.

Nakandala, D., Lau, H., \& Zhao, L. (2017). Development of a hybrid fresh food supply chain risk assessment model. International Journal of Production Research, 55(14), 4180-4195. http://dx.doi.org/10.1080/00207543.2016.1267413.

Oztaysi, B. (2014). 'A decision model for information technology selection using AHP integrated TOPSIS-Grey: the case of content management systems. Knowledge-Based Systems, 70, 44-54. http://dx.doi.org/10.1016/j.knosys.2014.02.010.

Parthiban, P., Abdul Zubar, H., \& Katakar, P. (2013). Vendor selection problem: a multi-criteria approach based on strategic decisions. International Journal of Production Research, 51(5), 1535-1548. http://dx.doi.org/10.1080/00207543.2012.709644.

Pasek, Z. J. (2011). Assessing inter-organizational dynamics of manufacturing service supply contracts. In S. Jain, R. Creasey \& J. Himmelspach (Eds.), Proceedings of the 2011 Winter Simulation Conference (WSC) (pp. 659-670). New York: IEEE. http://dx.doi. org/10.1109/WSC.2011.6147794.

Pereira, S. C. F., Scarpin, M. R. S., \& Ferreira Neto, J. (2020). Agri-food risks and mitigations: a case study of the Brazilian mango. Production Planning and Control. In press. http://dx.doi.org/10.1080/09537287.2020.1796134.

Prusak, A., Stefanów, P., Niewczas, M., \& Sikora, T. (2013). Application of the AHP in evaluation and selection of suppliers Research motives and objectives. In Proceedings of the 57th EOQ Congress Quality Renaissance: Co-creating a Viable Future (pp. 1-8). Tallinn, Estonia.

Pungchompoo, S., \& Sopadang, A. (2015). Confirmation and evaluation of performance measurement model for the Thai frozen shrimp chain. Business Process Management Journal, 21(4), 837-856. http://dx.doi.org/10.1108/BPMJ-06-2014-0053.

Rathore, R., Thakkar, J. J., \& Jha, J. K. (2017). A quantitative risk assessment methodology and evaluation of food supply chain. International Journal of Logistics Management, 28(4), 1272-1293. http://dx.doi.org/10.1108/IJLM-08-2016-0198.

Rostamzadeh, R., Ghorabaee, M. K., Govindan, K., Esmaeili, A., \& Nobar, H. B. K. (2018). Evaluation of sustainable supply chain risk management using an integrated fuzzy TOPSIS- CRITIC approach. Journal of Cleaner Production, 175, 651-669. http://dx.doi. org/10.1016/j.jclepro.2017.12.071.

Ruoning, X., \& Xiaoyan, Z. (1992). Extensions of the analytic hierarchy process in fuzzy environment. Fuzzy Sets and Systems, 52(3), 251-257. http://dx.doi.org/10.1016/0165-0114(92)90236-W.

Saaty, R. W. (1987). The analytic hierarchy process-what it is and how it is used. Mathematical Modelling, 9(3-5), 161-176. http:// dx.doi.org/10.1016/0270-0255(87)90473-8.

Sarkis, J., \& Dhavale, D. G. (2015). Supplier selection for sustainable operations: a triple-bottom-line approach using a Bayesian framework. International Journal of Production Economics, 166, 177-191. http://dx.doi.org/10.1016/j.jpe.2014.11.007.

Sen, D. K., Datta, S., \& Mahapatra, S. S. (2016). A TODIM-based decision support framework for G-resilient supplier selection in fuzzy environment. Asia-Pacific Journal of Operational Research, 33(5), 1650033. http://dx.doi.org/10.1142/S0217595916500330. 
Sepúlveda, W. S., Maza, M. T., \& Pardos, L. (2011). Aspects of quality related to the consumption and production of lamb meat: consumers versus producers. Meat Science, 87(4), 366-372. http://dx.doi.org/10.1016/j.meatsci.2010.11.013. PMid:21167649.

Silva, E. M., Ramos, M. O., Alexander, A., \& Jabbour, C. J. C. (2020). A systematic review of empirical and normative decision analysis of sustainability-related supplier risk management. Journal of Cleaner Production, 244, 118808. http://dx.doi.org/10.1016/j. jclepro.2019.118808.

Souliotis, A., Kotsalis, A., \& Bosku, G. (2017). Benchmarking between vegetable suppliers in Greece. Benchmarking: An International Journal, 24(6), 1-31.

Spisso, B. F., Nóbrega, A. W., \& Marques, M. A. (2009). Resíduos e contaminantes químicos em alimentos de origem animal no Brasil: histórico, legislação e atuação da vigilância sanitária e demais sistemas regulatórios. Ciencia \& Saude Coletiva, 14(6), 2091-2106. http://dx.doi.org/10.1590/S1413-81232009000600016. PMid:20069177.

Voss, M. D., Closs, D. J., Calantone, R. J., Helferich, O. K., \& Speier, C. (2009). The role of security in the food supplier selection decision. Journal of Business Logistics, 30(1), 127-155. http://dx.doi.org/10.1002/j.2158-1592.2009.tb00102.x.

Wang, C. N., Tsai, H.-T., Nguyen, V. T., Nguyen, V. T., \& Huang, Y.-F. (2020). A hybrid fuzzy analytic hierarchy process and the technique for order of preference by similarity to ideal solution supplier evaluation and selection in the food processing industry. Symmetry, 12(2), 211. http://dx.doi.org/10.3390/sym 12020211.

Wang, W. P. (2010). A fuzzy linguistic computing approach to supplier evaluation. Applied Mathematical Modelling, 34(10), $3130-3141$. http://dx.doi.org/10.1016/j.apm.2010.02.002.

Xiao, Z., \& Chen, W. (2010). A partner selection method based on risk evaluation using fuzzy soft set theory in supply chain. In D. Wu, M. Z. Xu, Z. J. Zhang \& Y. Fang (Eds.), Proceedings of the 1st International Conference on Sustainable Construction \& Risk Management (Vol. l-ll, pp. 317-323). China: UAPRESS.

Zadeh, L.A. (1965). Outline of a new approach to the analysis of complex systems and decision processes. IEEE Trans. Syst. Man Cybernet, 3(1973), 28-44.

Zimmer, K., Fröhling, M., Breun, P., \& Schultmann, F. (2017). Assessing social risks of global supply chains: a quantitative analytical approach and its application to supplier selection in the German automotive industry. Journal of Cleaner Production, 149, 96-109. http://dx.doi.org/10.1016/j.jclepro.2017.02.041. 